\title{
What is the importance of canal-to-diaphysis ratio on osteoporosis-related hip fractures?
}

\author{
Kanal-diyafiz oranının osteoporozla ilişkili kalça kırıklarında önemi nedir?
}

\author{
Hasan Hüseyin Bozkurt, MD'1, Mehmet Ali Tokgöz,MD'10, \\ Aliekber Yapar, MD'10, Osman Şahap Atik, MD²] \\ 'Department of Orthopaedics and Traumatology, Gazi University Faculty of Medicine, Ankara, Turkey \\ ${ }^{2}$ Orthopedic Surgery, Turkish Joint Diseases Foundation, Ankara, Turkey
}

\begin{abstract}
Objectives: This study aims to investigate whether the ratio of the canal-to-diaphysis in femoral subtrochanteric region is helpful in determining risk before hip fracture.

Patients and methods: The study group consisted of 116 patients with osteoporotic hip fractures (26 males, 90 females; mean age 77.8 years; range, 61 to 89 years) and the control group consisted of 56 subjects (11 males, 45 females; mean age 75.3 years; range, 60 to 83 years). The canal-to-diaphysis ratio of patients in the study group was measured on plain radiographs. The results of the affected side and intact side were compared. To ensure the interobserver reliability of the measurements and to minimize technical errors, the assessments were performed twice (two weeks apart) by two different orthopedic surgeons.
\end{abstract}

Results: The canal-to-diaphysis ratio was significantly increased in patients with hip fracture compared with the intact side of same patient $(\mathrm{p}<0.001)$ and control subjects $(\mathrm{p}<0.001)$. According to the results of the receiver operating characteristic analysis, canal-to-diaphysis ratio had a diagnostic value in predicting hip fracture in osteoporosis patients, and the limit value was approximately 0.53 (sensitivity: $81 \%$, specificity: $86 \%$ ). An index of 0.53 represents a risk of intertrochanteric hip fracture of $89 \%$.

Conclusion: This method can be easily applied by all physicians as X-ray device is readily accessible with low cost. The risk of hip fracture should be determined, osteoporosis should be evaluated, and treatment should be started in patients with high risk to take the necessary precautions before the fracture develops.

Keywords: Canal-to-diaphysis ratio, fracture risk, hip fracture, osteoporosis.

\section{$O ̈ Z$}

Amaç: Bu çalışmada femoral subtrokanterik bölge kanaldiyafiz oranının kalça kırığı öncesi riskin belirlenmesinde yararlı olup olmadığı araştırıldı.

Hastalar ve yöntemler: Çalışma grubu osteoporotik kalça kırıklı 116 hastadan (26 erkek, 90 kadın; ort. yaş 77.8 yıl; dağılım, 61-89 yıl), kontrol grubu ise 56 bireyden (11 erkek, 45 kadın; ort. yaş 75.3 yıl; dağılım, 60-83 yıl) oluştu. Çalışma grubundaki hastaların düz radyografilerinde kanaldiyafiz oranı ölçüldü. Etkilenen taraf ve sağlam tarafın sonuçları karşılaştırıldı. Ölçümlerin gözlemciler arasında güvenilirliğini sağlamak ve teknik hataları en aza indirmek için değerlendirmeler iki farklı ortopedik cerrah tarafından iki kere (iki hafta ara ile) yapıldı.

Bulgular: Kalça kırıklı hastalarda kanal-diyafiz oranı aynı hastanın sağlam tarafına $(\mathrm{p}<0.001)$ ve kontrol deneklerine $(\mathrm{p}<0.001)$ göre anlamlı olarak artmıştı. Alıcı işletim karakteristik analizinin sonuçlarına göre, osteoporoz hastalarında kalça kırığını öngörmede kanal diyafiz oranı tanısal bir değere sahipti ve sınır değer yaklaşık 0.53 (duyarlılık: \%81, özgüllük: \%86) idi. 0.53'lük indeks, \%89'luk intertrokanterik kalça kırığı riskini temsil eder.

Sonuç: X-ışını cihazına düşük maliyetle rahatlıkla erişilebildiği için bu yöntem tüm hekimler tarafından kolayca uygulanabilir. Yüksek riskli hastalarda kalça kırığ1 riski belirlenmeli, osteoporoz değerlendirilmeli ve kırık gelişmeden gerekli önlemleri almak için tedaviye başlanmalıdır.

Anahtar sözcükler: Kanal-diyafiz oranı, kırık riski, kalça kırığı, osteoporoz.

Received: July 17, 2019 Accepted: August 09, 2019 Published online: October 24, 2019

Correspondence: Mehmet Ali Tokgöz, MD. Gazi Üniversitesi Tıp Fakültesi Ortopedi ve Travmatoloji Anabilim Dalı, 06500 Beşevler, Ankara, Turkey. Tel: +90 312 - 2025528 e-mail: m.alitokgoz@gmail.com 
Osteoporosis is a major global health problem with significant economic consequences and adverse impacts on quality of life. This insidious disease usually presents with fractures resulting from a low-energy trauma. ${ }^{[1]}$ Hip fractures are the most devastating complication of osteoporosis due to significant morbidity and mortality risks. Hip fractures are a major cause of disability, functional impairment, and death in elderly people. An aggressive approach to investigate, assess and manage the fracture and fall risks of an individual is necessary to reduce hip fracture rate and associated complications. ${ }^{[2,3]}$

The most preferred and accepted diagnostic technique for the assessment of fracture risk after osteopenia and osteoporosis is the measurement of bone mineral density (BMD) with dual-energy X-ray absorptiometry (DXA). This technique is limited due to its low accessibility, high capital costs, and low sensitivity. ${ }^{[4]}$ Several studies have shown that bone mass and density are associated with osteoporotic fracture risk. ${ }^{[5-8]}$ However, the disadvantage is that BMD alone is not optimal for the detection of individuals with a high risk of fracture.$^{[9]}$ It is understood that fracture risk depends not only on BMD, but also on bone strength, which includes bone turnover, bone architecture, etc. Factors like age, previous osteoporotic fracture, parental fracture or osteoporosis history also increase fracture risk. ${ }^{[10,11]}$ For these reasons, more easily accessible and cost-effective methods are needed to diagnose osteoporosis and particularly to predict and prevent hip fractures. In this study, we aimed to investigate whether the ratio of the canal-to-diaphysis in femoral subtrochanteric region is helpful in determining risk before hip fracture.

\section{PATIENTS AND METHODS}

This study was conducted on patients admitted to Gazi University Faculty of Medicine Department of Orthopedics and Traumatology between February 2013 and January 2018. A total of 116 patients (study group) (26 males, 90 females; mean age 77.8 years; range, 61 to 89 years) presenting with osteoporotic hip fractures and 56 subjects (control group) (11 males, 45 females; mean age 75.3 years; range, 60 to 83 years) from a similar epidemiological group without osteoporosis and fracture were included in the study. Seventy-two patients in the study group had femoral neck fractures, and 44 had intertrochanteric fractures. A written informed consent was obtained from each patient. The study was conducted in accordance with the principles of the Declaration of Helsinki.

Patients under 60 years of age, those with pathological fractures, displaced trochanter minor fractures, secondary osteoporosis, fractures due to high-energy trauma, and those who had not undergone appropriate radiography were excluded.

All patients underwent a conventional radiography by the same radiology technician team to show both hips and femoral diaphysis with the same device. When radiographies were taken, either both patellae should be facing forward or lower extremities should be internally rotated by $15^{\circ}-20^{\circ}$ to accommodate femoral anteversion in anteroposterior hip radiographs. The images were recorded by accessing
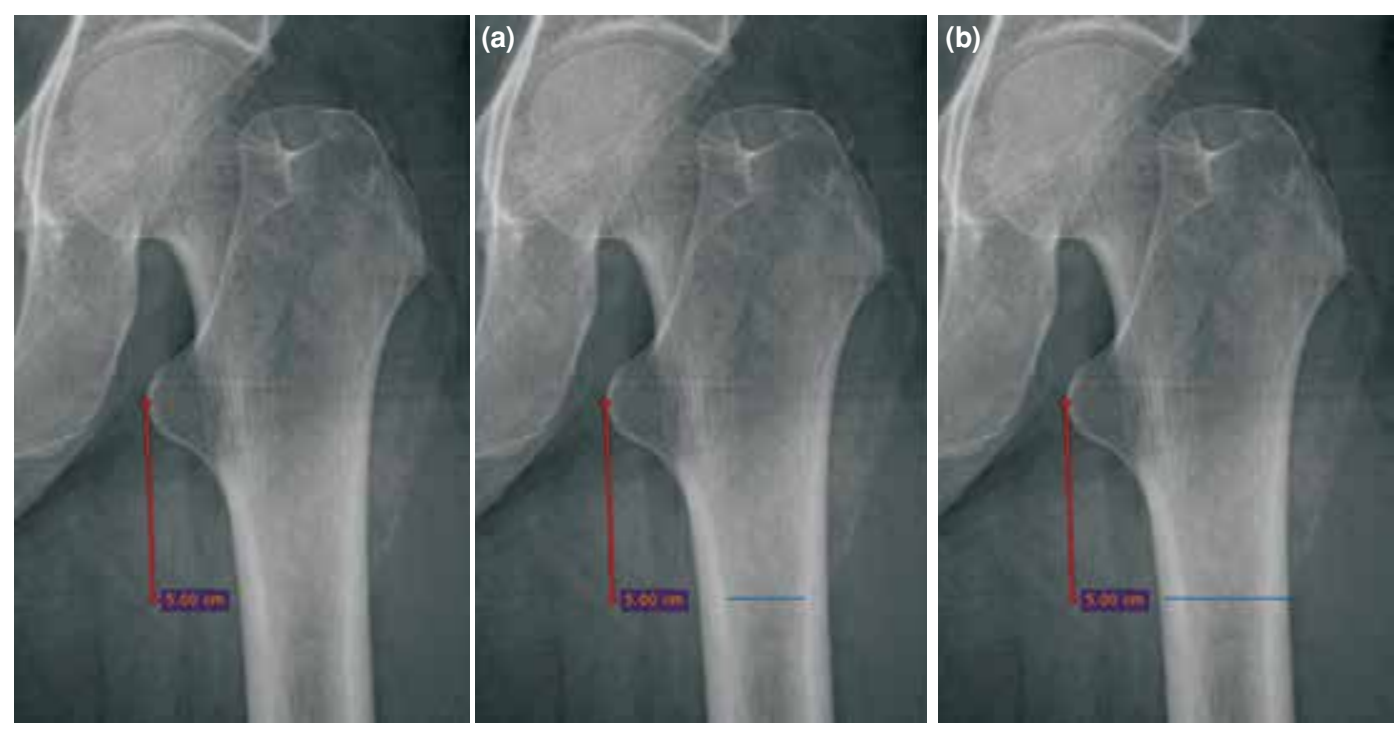

Figure 1. Vertical line from mid-lesser trochanter to $5 \mathrm{~cm}$ below. (a) Canal width (b) and diaphysis width are seen. 
the electronic archive of the hospital. All radiographs were numbered sequentially without data such as age, name or identification number. All radiographs were electronically opened and measured on the same computer using RadiAnt DICOM Viewer Version 4.0.3 software (Poznan, Poland).

The measurements were performed at $5 \mathrm{~cm}$ distal from trochanter minor at the anteroposterior images with the appropriate hip rotation. That femoral level was chosen because it was the anatomical intersection of the diaphysis and subtrochanteric region. The width of the femoral canal and diaphysis were measured at that level, and the canal-to-diaphysis ratio was calculated with these two measurements (Figure 1).

The canal-to-diaphysis ratio of the patients in the study group was calculated for both sides. Then, the results of the affected side and the intact bone were compared. Afterwards, the results of the study and control groups were statistically compared. To ensure the interobserver reliability of the measurements and to minimize technical errors, the assessments were performed twice (two weeks apart) by two different orthopedic surgeons.

Receiver operating characteristic (ROC) curve analysis and AUC (area under the ROC curve) were performed to determine whether the canalto-diaphysis ratio had an optimum cut-off value to distinguish the hip fractures. AUC can only take a value between 0 and 1 . The closer AUC is to 1 , the

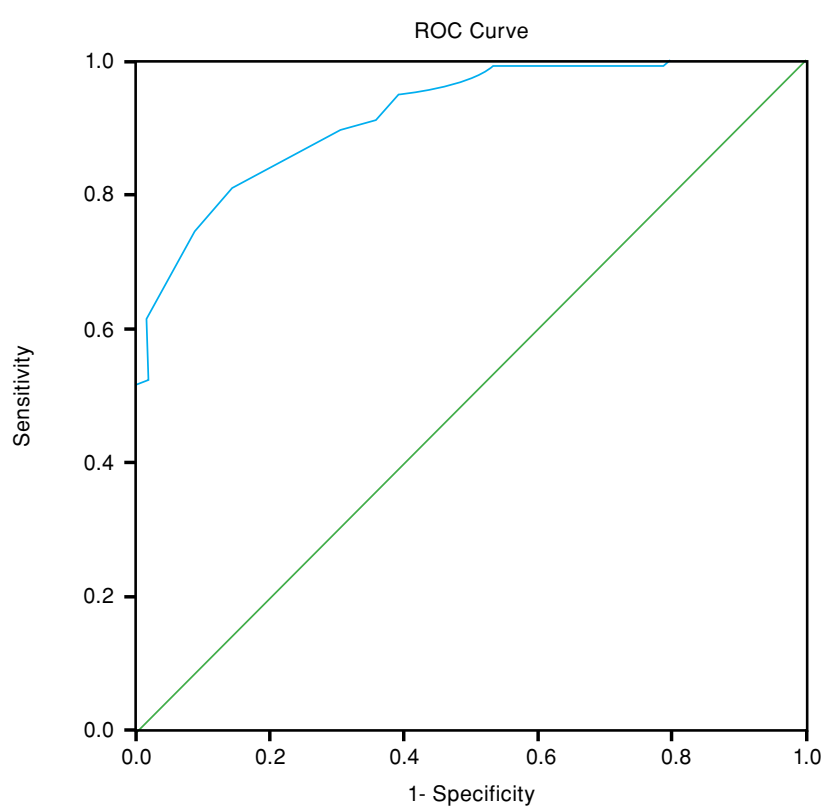

Figure 2. Receiver operating characteristic curve of a total of 172 individuals included in study for canal-to-diaphysis ratio. ROC: Receiver operating characteristic. better the overall diagnostic performance of the test, and a test with an AUC value of 1 is one that is perfectly accurate. The practical lower limit for the AUC of a diagnostic test is $0.5 .^{[12]}$ The sensitivity, specificity, positive predictive value, and negative predictive value of significant limit values were estimated. Univariate logistic regression analyses were used to assess the effect of canal-to-diaphysis ratio on osteoporotic hip fracture. These data are presented as odds ratio (OR) with $95 \%$ confidence intervals (95\% CIs).

\section{Statistical analysis}

All statistical analyses were performed using the IBM SPSS version 23.0 software (IBM Corp., Armonk, NY, USA), and a $p$ value $<0.05$ was considered to be statistically significant. In the statistical analysis, categorical variables are given as numbers and percentages, and continuous variables are presented as mean \pm standard deviation and as median (min-max value) for descriptive analyses. Pearson's chi-squared test, Fisher's chi-squared test and continuity correction chi-squared test were used for the comparison of categorical variables in independent groups. The conformity of continuous variables to normal distribution was evaluated using visual (histogram and probability graphs) and analytical methods (Kolmogorov-Smirnov/Shapiro-Wilk tests). Normality analysis revealed that all data sets were not normally distributed. Student's t-test (independent groups) and paired sample t-test (dependent groups) were used in the group comparison analysis performed on data conforming to normal distribution. The MannWhitney $U$ test was used for the comparison of data sets that were not normally distributed for the variables.

\section{RESULTS}

The mean canal-to-diaphysis ratio of the study group was 0.62 (range, 0.42-0.85) for the affected side and 0.54 (range, 0.38-0.82) for the intact side, and this difference was statistically significant $(\mathrm{p}<0.001)$. When the canal-to-diaphysis ratios of the control group were compared, no difference was found between the sides, as expected. The mean canal-to-diaphysis ratio of the

\section{TABLE I}

Area under the curve, 95\% confidence interval and $p$ value for canal-to-diaphysis ratio

\begin{tabular}{lccc}
\hline ROC model & AUC & $p$ & $95 \% \mathrm{Cl}$ \\
\hline Canal-to-diaphysis ratio & 0.918 & $<0.001$ & $0.878-0.957$ \\
\hline
\end{tabular}

ROC: Receiver operating characteristic; AUC: Area under the curve; $\mathrm{Cl}$ : Confidence interval. 
TABLE II

Statistical parameters of various diagnostic approaches for predicting osteoporotic hip fracture

\begin{tabular}{lcccc}
\hline Cut-off value & Sensitivity (\%) & Specificity (\%) & PPV (\%) & NPV (\%) \\
\hline$\geq 0.53$ & 81 & 86 & 73.9 & 66.7 \\
\hline PPV: Positive predictive value; NPV: Negative predictive value.
\end{tabular}

control group was 0.47 (range, 0.30-0.61) for the right side and 0.46 (range, 0.27-0.61) for the left side There was a statistically significant difference between the ratios of the control group and the affected side of the study group $(\mathrm{p}<0.001)$.

The ROC analysis was performed to determine a cut-off level for the canal-to-diaphysis ratio to determine hip fracture risk in osteoporotic patients. According to the results, the AUC was found to be statistically significant $(p<0.001)$. As a result of ROC analysis, the canal-to-diaphysis ratio was observed to be diagnostic in predicting hip fracture in osteoporosis patients (Figure 2, Table 1) and the limit value was approximately 0.53 (sensitivity: $81 \%$, specificity: $86 \%$ ) (Table 2).

The patients included in the study were re-grouped by using the cut-off value of the canal-to-diaphysis ratio obtained by the ROC analysis. When these groups were investigated, the incidence of hip fracture was found to be $89 \%(98 / 110)$ in patients with a canalto-diaphysis ratio of 0.53 and above. It was also found that hip fracture risk was 20 times higher in these patients (OR=19.96; 95\% CI: 8.85-44.9; $\mathrm{p}<0.001)$ (Table 3).

\section{DISCUSSION}

In the current study, 116 patients with hip fractures and 56 subjects without fractures were evaluated, and the findings of the study supported the data regarding the relationship between cortical thickness and osteoporotic hip fractures.

When the cancellous bone is completely removed from the femoral neck, bone strength has been

\section{TABLE III}

Hip fracture risk analysis in formed groups after new grouping according to cut-off value $(n=172)$

\begin{tabular}{ccccc}
\hline & $\mathrm{n}^{*}$ & $\%$ & $\begin{array}{c}\mathrm{OR}^{* *} \\
(95 \% \mathrm{Cl})\end{array}$ & $p$ \\
\hline$<0.53$ & $18 / 62$ & 29 & 1 (reference) & 0.001 \\
$\geq 0.53$ & $98 / 110$ & 89 & $\begin{array}{c}19.96 \\
(8.85-44.98)\end{array}$ & \\
\hline
\end{tabular}

* Patients with hip fracture/all subjects in group; ${ }^{* \star} \mathrm{OR}$ : Odds ratio; $\mathrm{Cl}$ : Confidence interval. shown to be reduced by less than $10 \%$; this shows that the main structure resisting the fracture of the proximal femur is the cortical part of the bone. ${ }^{[13]}$ Cortical bone is further thinned with increasing age. ${ }^{[14,15]}$ Ward et al. ${ }^{[16]}$ showed that cortical bone decreased by $14 \%$ every 10 years in adults over 50 years of age. It has been presented in multiple studies that cortical thickness reduction may result in osteoporotic fractures. ${ }^{[17,18]}$

Sah et al. ${ }^{[19]}$ presented that femurs with small radiographic cortical thickness indices had lower T-scores in DXA tests. They presented that finding a radiographic hip cortical thickness index with a value at or below 0.40 should be an alert for referral to osteoporosis evaluation and might be directly related to fracture.

In a study conducted with patients with intertrochanteric fractures, the risk of hip fracture was $85.8 \%$ in the case of a canal-to-diaphysis ratio of 0.62 measured by conventional radiography. ${ }^{[4]}$ In another study, it was specified that an increased canal-to-diaphysis ratio was associated with increased incidence of femoral neck fracture and intertrochanteric hip fracture. ${ }^{[20]}$ It was found in the current study that if the ratio of the canal-diaphysis was at or above 0.53 , osteoporotic hip fracture risk was at $89 \%$. Another finding of the current study is that if the clinician observes any difference between the affected side and the intact side on femoral cortical thickness of the same patient in conventional radiography, fracture risk can be evaluated by calculating canal-to diaphisis ratio.

There are some limitations in this study. First, the sample size is small. Second, the calibration of the X-ray machine and the standardization of the technique are crucial for healthy results.

In conclusion, this method can be easily applied by all physicians as the X-ray device is readily accessible with low cost. Osteoporosis evaluation should be absolutely performed when fractures involving the wrist, shoulder or vertebrae develop due to low-energy trauma. In patients with high risk, the risk of hip fracture should be determined, osteoporosis should be evaluated, and treatment 
should be started to take the necessary precautions before the fracture develops.

\section{Declaration of conflicting interests}

The authors declared no conflicts of interest with respect to the authorship and/or publication of this article.

\section{Funding}

The authors received no financial support for the research and/or authorship of this article.

\section{REFERENCES}

1. Moradi R, Atik OS. Are orthopedic surgeons more aware of medical treatment of osteoporotic fractures in the last decade? Eklem Hastalik Cerrahisi 2014;25:80-4

2. Cauley JA. Public health impact of osteoporosis. J Gerontol A Biol Sci Med Sci. 2013;68:1243-51

3. Menzies IB, Mendelson DA, Kates SL, Friedman SM. Prevention and clinical management of hip fractures in patients with dementia. Geriatr Orthop Surg Rehabil 2010;1:63-72.

4. Rostislav N, Nahum R, David N, Yaron B, Sergey M, Doron $\mathrm{N}$, et al. Canal-to-Diaphysis Ratio as an OsteoporosisRelated Risk Factor for Hip Fractures. Orthopedics 2015;38:e457-61.

5. Lang SM, Moyle DD, Berg EW, Detorie N, Gilpin AT, Pappas NJ Jr, et al. Correlation of mechanical properties of vertebral trabecular bone with equivalent mineral density as measured by computed tomography. J Bone Joint Surg [Am] 1988;70:1531-8.

6. Rice JC, Cowin SC, Bowman JA. On the dependence of the elasticity and strength of cancellous bone on apparent density. J Biomech 1988;21:155-68.

7. Heaney RP, Abrams S, Dawson-Hughes B, Looker A, Marcus R, Matkovic V, et al. Peak bone mass. Osteoporos Int 2000;11:985-1009.

8. Hawker GA, Jamal SA, Ridout R, Chase C. A clinical prediction rule to identify premenopausal women with low bone mass. Osteoporos Int 2002;13:400-6.
9. Assessment of fracture risk and its application to screening for postmenopausal osteoporosis. Report of a WHO Study Group. World Health Organ Tech Rep Ser 1994;843:1-129.

10. Atik OS. Is DXA the gold standard? Eklem Hastalik Cerrahisi 2011;22:63.

11. Bozkurt HH, Atik OŞ, Tokgöz MA. Can distal radius or vertebra fractures due to low-energy trauma be a harbinger of a hip fracture? Eklem Hastalik Cerrahisi 2018;29:100-3.

12. Park SH, Goo JM, Jo CH. Receiver operating characteristic (ROC) curve: practical review for radiologists. Korean J Radiol 2004;5:11-8.

13. Holzer G, von Skrbensky G, Holzer LA, Pichl W. Hip fractures and the contribution of cortical versus trabecular bone to femoral neck strength. J Bone Miner Res 2009;24:468-74.

14. Li Y, Lin J, Cai S, Yan L, Pan Y, Yao X, et al. Influence of bone mineral density and hip geometry on the different types of hip fracture. Bosn J Basic Med Sci 2016;16:35-8.

15. Li Y, Zhuang H, Lin J, Yao X, Yu H, Pan Y. The effect of age on the bone mineral density and cortical thickness of femoral neck. Chinese J Osteoporosis 2012;2012:2.

16. Ward KA, Adams JE, Hangartner TN. Recommendations for thresholds for cortical bone geometry and density measurement by peripheral quantitative computed tomography. Calcif Tissue Int 2005;77:275-80.

17. Zhuang $\mathrm{H}, \mathrm{Li} \mathrm{Y}, \mathrm{Lin} \mathrm{J}$, Cai $\mathrm{D}$, Cai $\mathrm{S}$, Yan $\mathrm{L}$, et al. Cortical thickness in the intertrochanteric region may be relevant to hip fracture type. BMC Musculoskelet Disord 2017:18;18:305.

18. Rodríguez-Soto AE, Fritscher KD, Schuler B, Issever AS, Roth T, Kamelger F, et al. Texture analysis, bone mineral density, and cortical thickness of the proximal femur: fracture risk prediction. J Comput Assist Tomogr 2010;34:949-57.

19. Sah AP, Thornhill TS, LeBoff MS, Glowacki J. Correlation of plain radiographic indices of the hip with quantitative bone mineral density. Osteoporos Int 2007;18:1119-26.

20. Ellanti P, Mohan K, Moriarity A, Hogan N, McCarthy T. Canal to diaphysis ratio as a risk factor for hip fractures and hip fracture pattern. SICOT J 2017;3:64. 